Int. Archs Allergy appl. Immun. 1987;82:I-VII

\title{
Contents, Vol. 82, 1987
}

Vol. 82, 1987

International Archives

of Allergy and Applied

Immunology

Founded 1950 by D. Harley, P. Kallós, W. Löffler and F.W. Wittich

Continued by E.A. Brown (1952-1954), W. Kaufman (1955-1967),

F. Hahn (1961-1972), H.C. Goodman (1963-1975) and R.R.A. Coombs (1955-1984)

Editors-in-Chief

L.Å. Hanson, Göteborg

P. Kallós, Helsingborg

K. Kano, Tokyo

F. Milgrom, Buffalo, N.Y.

K. Rother, Heidelberg

Z. Trnka, Basel

G.B. West, Epsom

Contributing Editors

C.J. Abeyounis, Buffalo, N.Y.

N.F. Adkinson, Jr., Baltimore, Md.

St. Ahlstedt, Uppsala

B. Albini, Buffalo, N.Y.

G. Andres, Buffalo, N.Y.

E.L. Becker, Farmington, Conn.

N. Blomqvist, Göteborg

W.E. Brocklehurst, Windlesham

A. Capron, Lille

A. Cerletti, Basel

C.G. Cochrane, La Jolla, Calif.

B. Diamant, Copenhagen

P. Dukor, Basel

L. Edebo, Göteborg

S. Elsayed, Bergen

W.P. Faulk, Nice

P.G.H. Gell, Birmingham

I. Glazer, Tel Aviv

R.A. Good, St. Petersburg, Fla.

M. Hess, Bern

L. Hudson, Beckenham

H. Isliker, Lausanne 
S.G.O. Johansson, Stockholm

E.A. Kabat, New York, N.Y.

M. Miyasaka, Basel

W. Müller-Ruchholtz, Kiel K.D. Murrell, Beltsville, Md.

F. Ørskov, Copenhagen

Ö. Ouchterlony, Göteborg

Z. Ovary, New York, N.Y.

P. Perlmann, Stockholm

E. Pick, Tel Aviv

M. Plaut, Baltimore, Md. R.E. Reisman, Buffalo, N.Y.

G. Riethmüller, München

M. Roitt, London

U. Rother, Heidelberg G. Sandberg, Stockholm H.D. Schlumberger, Wuppertal K.H. Schulz, Hamburg A. Sehon, Winnipeg

F. Shakib, Derby

O. Strannegård, Göteborg A. Szentivanyi, Tampa, Fla. O. Tönder, Bergen

G. Torrigiani, Geneve

J.L. Turk, London

E.R. Unanue, Boston, Mass. B.H. Waksman, New York, N.Y. G. Wick, Innsbruck ffi(B

S. Karger · Medical and Scientific Publishers · Basel · München $\square$ Paris · London · New York · New Delhi $\cdot$ Singapore $\cdot$ Tokyo $\cdot$ Sydney

Drug Dosage

The authors and the publisher have exerted every effort to ensure that drug selection and dosage set forth in this text are in accord with current recommendations and practice at the time of publication. However, in view of ongoing research, changes in government regulations, and the constant flow of information relating to drug therapy and drug reactions, the reader is urged to check the package insert for each drug for any change in indications and dosage and for added warnings and precautions. This is particularly important when the recommended agent is a new and/or infrequently employed drug.

All rights reserved.

No part of this publication may be translated into other languages, reproduced or utilized in any form or by any means, electronic or mechanical, including photocopying, recording, microcopying, or by any information storage and retrieval system, without permission in writing from the publisher or, in the case of photocopying, direct payment of a specified fee to the Copyright Clearance Center (see 'Information for Readers and Subscribers').

(C) Copyright 1987 by S. Karger AG, P.O. Box, CH-4009 Basel (Switzerland) Printed in Switzerland by Buchdruckerei Basler-Zeitung AG, Basel

Contents Vol. 82,1987

No. 1

Editorial

Pseudo-Allergic Reactions - PAR Kallós, P.; Schlumberger, H.D.

1

Original Paper

Anaphylatoxin-Induced Neutrophil Chemotaxis and Aggrega

tion. Limited Aggregation and Specific Desensitization In 
duced by Human C3a and Synthetic C3a Octapeptides

Nagata, S.; Glovsky, M.M.; Kunkel, S.L 4

Increased Natural Killer Cell Activity in Sarcoidosis

Hall, T.J.; Hudspith, B.N.; Johnson, N.McL; Brostoff, J. . 10

Immunotherapy in a Case of AIDS with Kaposi's Sarcoma -

An Unsuccessful Attempt with Recombinant Alpha-2 In-

terferon Followed by Isoprinosine

Roupe, G.; Håkansson, C; Löwhagen, G.B 17

Eosinophil Chemotactic Lymphokine Produced by Spleen

Cells of Schistosoma japonicum-lnfecteå Mice

Owhashi, M.; Nawa, Y 20

Mechanism of Antianaphylactic Action of B-Agonists in Aller

gic Inflammation of Air Pouch Type in Rats

Ohuchi, K.; Hirasawa, N.; Takeda, H.; Asano, K.; Wata-

nabe, M.; Tsurufuji, S 26

Adverse Effects of Acetylcysteine on Human and Guinea Pig

Bronchial Asthma in vivo and on Human Fibroblasts and

Leukocytes in vitro

Dorsch, W.; Auch, E.; Powerlowicz, P 33

Modulatory Effects of Streptococcus mutans on Human Neu

trophil Adherence and Deoxyglucose Uptake

Seow, W.K.; Seymour, G.J.; Thong, Y.H 40

Detection of Mouse IgE by CELISA

Gavériaux, C; Renard, P.; Loor, F 46

Vitamin A Acetate as a Regulator of Accessory Cell Function

in Delayed-Type Hypersensitivity Responses

Katz, D.R.; Mukherjee, S.; Maisey, J.; Miller, K 53

Platelet-Activating Factor in Late Asthmatic Response

Nakamura, T.; Morita, Y.; Kuriyama, M.; Ishihara, K.;

Ito, K; Miyamoto, T 57

Long-Term Follow-Up of Histamine Turnover in Mastocytosis

Roupe, G.; Granerus, G 62

Mechanism of Action of an Antiallergic Agent, Amlexanox (AA-673), in Inhibiting Histamine

Release from Mast Cells. Acceleration of cAMP Generation and Inhibition of Phosphodiesterase

Makino, H.; Saijo, T.; Ashida, Y.; Kuriki, H.; Maki, Y. . 66

Antigenic Stimulation with Proteins of Cow's Milk via the

Oral Route in Guinea Pigs and Rats. 1. Measurement of

Antigenically Intact $\beta$-Lactoglobulin and Casein in the

Gastrointestinal Contents of Duodenum, Jejunum and

Ileum

Koritz, T.N.; Suzuki, S.; Coombs, R.R.A 72

Antigenic Stimulation with Proteins of Cow's Milk via the

Oral Route in Guinea Pigs and Rats. 2. Antibodies to ß-

Lactoglobulin Secreted into the Alimentary Canal and

Serum

Suzuki, S.; Koritz, T.N.; Coombs, R.R.A 76 
Comparison of Arachidonic Acid Metabolism in Nasal Polyps

and Eosinophils

Smith, D.M.; Gerrard, J.M.; White, J.G

Immunopathology of Experimental Schistosoma mansoni: Im-

munohistochemical Localization of Parasite Antigens in

the Host Tissue (With 1 color plate)

Abdul-Aal, G.M.; Attallah, A.M 89

Changes of House Dust Mite-Specific IgE, IgG and IgG Subclass Antibodies during

Immunotherapy in Patients with Perennial Rhinitis

Nakagawa, T.; Kozeki, H.; Katagiri, J.; Fujita, Y.; Yama-

shita, N.; Miyamoto, T.; Skvaril, F 95

Similarities between IgE in Human Feces and a Chymotryp-

sin-Digest of an IgE Myeloma Protein

Kolmannskog, S 100

Short Communication

Activity of Nedocromil Sodium in Mast-Cell-Dependent Reactions in the Rat Riley, P.A.;

Mather, M.E.; Keogh, R.W.; Eady, R.P. ... 108

Book Reviews Ill

No. 2

Original Paper

Distribution of a Guinea Pig Lymphocyte Cell Surface Antigen

of Defined Function, as Detected by the Mouse Mono

clonal Antibody MSgp 1

Healey, D.G.; Parker, D.; Turk, J.L 113

An Antigenic Determinant Common to Lymphocytes and Langerhans Cells of the Guinea Pig

Healey, D.G.; Baker, D.; Gschmeissner, S.E.; Turk, J.L. . 120

IV

Contents

An Immunochemical Investigation of the Allergens from As-

caris suum Perienteric Fluid. Cross-Reactivity, Molecular

Weight Distribution and Correlation with Phosphorylcho-

line-Containing Components

McWilliam, A.S.; Stewart, G.A.; Turner, K.J 125

Effect of Human Interferon on Different Functions of Human

Neutrophils and Eosinophils

Saito, H.; Hayakawa, T.; Yui, Y.; Shida, T 133

Clonal Analysis of T Lymphocytes Infiltrating the Thyroid Gland in Hashimoto's Thyroiditis

Bagnasco, M.; Ferrini, S.; Venuti, D.; Prigione, I.; Torre, G.;

Biassoni, R.; Canonica, G.W 141

Immunocytochemical Mapping of IgE/IgG Binding Sites within the Birch Pollen Grain Using

Serum from a Patient Undergoing Hyposensitization Therapy. Comparison with Biochemically

Determined Data Grote, M.; Kalveram, K.; Fromme, H.G.; Forck, G. ... 147

Antibody Synthesis in the Rat Liver: An Association between Antibody-Forming Cells in the

Liver and Biliary Antibodies following Intravenous Injection of Horse Eryth-rocytes Carter, L;

Barrington, P.J.; Cooper, G.N.; Jackson, G.D.F. 153 
Effect of Polymeric IgG on Human Monocyte Functions

Mannhalter, J.W.; Ahmad, R.; Wolf, H.M.; Eibl, M.M. . 159

A Murine Anti-Sheep T8 Monoclonal Antibody, ST-8, that Defines the Cytotoxic T Lymphocyte Population Ezaki, T.; Miyasaka, M.; Beya, M.-F.; Dudler, L.; Trnka, Z. 168

Production of an International Reference Standard Alternaria

Extract. Testing of Candidate Extracts

Helm, R.M.; Squillace, D.L.; Aukrust, L.; Borch, S.M.;

Baer, H.; Bush, R.K.; Løwenstein, H.; Znamirowski, R.;

Nitchuk, W.; Yunginger, J.W 178

Further Studies of Patients with Both Honeybee- and Yellow-

Jacket-Venom-Specific IgE

Reisman, R.E.; Wypych, J.I.; Lazell, M.I 190

Regulation of Antibody-Dependent Cellular Cytotoxicity in

Multiple Sclerosis by Central Nervous System Hormones

Merrill, J.E.; Mohlstrom, C 195

Immunohistologic Comparison between Armadillo-Derived Leprosin and Standard Lepromin

Skin Tests in Leprosy Patients

Narayanan, R.B.; Ramu, G.; Sinha, S.; Sengupta, U.;

Gupta, CM 202

Suppression of Murine IgE Responses with Amino Acid Poly

mer/Allergen Conjugates. V. By Intranasal Administration

Henderson, D.C.; Wheeler, A.W.; Moran, D.M 208

Short Communications

Release of Thromboxane B2 and Leukotriene C4 and Reduc

tion in Renal Perfusion in Experimental Anaphylactic

Reaction of Isolated Guinea Pig Kidney

Assem, E.S.K.; Abdullah, N.A 212

Ionophore-Stimulated Rat Basophilic Leukemia Cells Produce

PAF-Acether

Purdon, A.D.; Yang, D.-C; Smith, S.; Smith, J.B 215

Neonatal IgE Injections Do Not Modify Nippostrongylus brasiliensis-lnduced and Mercuric

Chloride-Induced IgE Increase in the Rat Manouvriez, P.; Hirsch, F.; Sapin, C; Druet, P.; Bazin, H. 218

Antigen-Induced Formation of a Lymphokine with a Possible

Role as a Mediator of the Late Component of Dual Allergic

Reaction

Ezeamuzie, I.C.; Assem, E.S.K

221

No. 3-4

231

In Honour of Paul Kallós

Dukor, $\mathrm{P}$

Carl Prausnitz Memorial Lecture

Immunoprecipitation in Court - The Chamberlain Case

Ouchterlony, Ö

Immune-Related Cellular Responses in Mucosal Membrane

Mast-Cells 
The Role of Mast Cells in Inflammatory Processes: Evidence for Nerve/Mast Cell Interactions Bienenstock, J.; Tomioka, M.; Matsuda, H.; Stead, R.H.; Quinonez, G.; Simon, G.T.; Coughlin, M.D.; Denburg, J.A. 238

Mutual Phenotypic Changes between Connective Tissue Type and Mucosal Mast Cells

Kitamura, Y.; Kanakura, Y.; Sonoda, S.; Asai, H.; Nakano, T. 244

Mucosal Mast Cells in the Rat and in Man

Enerbäck, L 249

Investigations of Rat Mast Cell Heterogeneity

Befus, D.; Swieter, M.; Fujimaki, H.; Lee, T 256

In vivo Increase of Cutaneous Mast Cells in Response to Spe

cific Mediators and Ascaris Antigen

Czarnetzki, B.M.; Mecklenburg, G 259

Beige Mouse Mast Cells Generated in vitro: Ultrastructural

Analysis of Maturation Induced by Sodium Butyrate and of

IgE-Mediated, Antigen-Dependent Degranulation

Dvorak, A.M.; Hammel, I.; Galli, S.J 261

Analysis of Mast Cell Function in Biological Responses Not

Involving IgE

Galli, S.J.; Wershil, B.K.; Mekori, Y.A 269

Anti-Idiotypic Antibodies as Staphylococcal Enterotoxin Re

ceptor Probes on Monkey Mast Cells

Bamberger, U.; Scheuber, P.H.; Sailer-Kramer, B.; Ham

mer, D.K 272

Changes in Nasal Mast Cell Numbers In and Out of the Pollen

Season

Viegas, M.; Gomez, E.; Brooks, J.; Davies, R.J 275

Seasonal Variation of Mast Cell Function in Human Adenoid Tissues

Schmutzler, W.; Amandi, M.; Aniol, M.; Braam, U.;

Eichelberg, D.; Greven, T.; Kortemeier, A.; Schmitz, F.J.;

Ziesche, R 277

Mast Cell Histamine Release Induced by Intermediate Prod

ucts of Arachidonic Acid Metabolism

Masini, E.; Palmerani, B.; Bani-Sacchi, T.; Giannella, E.;

Fantozzi, R.; Mannaioni, P.F 279

Contents

$\mathrm{V}$

Time-Course of IgE Binding to Rat Peritoneal Cells after Sen-

sitization with Alum-Adsorbed Ovalbumin and Bordetella

pertussis

Behrendt, $\mathrm{H} 283$

Staphylococcal Enterotoxin B as a Nonimmunological Mast

Cell Stimulus in Primates: The Role of Endogenous Cystei-

nyl Leukotrienes

Scheuber, P.H.; Denzlinger, C; Wilker, D.; Beck, G.;

Keppler, D.; Hammer, D.K 289 
The Role of Histamine in Allergen and Adenosine-Induced

Bronchoconstriction

Rafferty, P.; Beasley, R.; Southgate, P.; Holgate, S 292

Purification of Serum Proteins with Inhibitory Activity on the

Histamine Release in vitro and/or in vivo

Theobald, K; Gross-Weege, W.; Keymling, J.; König, W. . 295 The Mast Cell and Signs of

Pulmonary Fibroblast Activation in

Sarcoidosis

Bjermer, L.; Engström-Laurent, A.; Thunell, M.; Hällgren, R. 298

Macrophages and Thrombocytes

Accessory Molecules in T Lymphocyte Activation

Miller, J.F.A.P302

Platelets as Effectors in Immune and Hypersensitivity Reactions

Capron, A.; Joseph, M.; Ameisen, J.C.; Capron, M.; Pancré,

V.; Auriault, C307

Thromboxane B2 Synthesis in Human Platelets Induced by the

Late Complement Components C5b-9

Betz, M.; Seitz, M.; Hänsch, G.M 313

Effect of the Late Complement Components C5b-9 on Human

Monocytes: Release of Prostanoids, Oxygen Radicals and of

a Factor Inducing Cell Proliferation

Hänsch, G.M.; Seitz, M.; Betz, M 317

Basophils and Eosinophils

Contribution of Basophil/Mast Cell and Eosinophil Growth and Differentiation to the Allergic

Tissue Inflammatory Response

Denburg, J.A.; Otsuka, H.; Ohnisi, M.; Ruhno, J.; Bienen-

stock, J.; Dolovich, J 321

Activation of Basophils and Mast Cells for Mediator Release

Ishizaka, T.; White, J.R.; Saito, H 327

Eosinophil Activation in Allergic Disease

Venge, P.; Håkansson, L.; Peterson, C.G.B 333

Biochemical Characterization of the Human Basophil-Pro-moting Activity

Stadler, B.M.; Hirai, K; Brantschen, S.; Nakajima, K;

Week, A.L. de 338

Mediator Release from Basophilic Cells Derived from Cultured Cord Blood Cells

Iikura, Y.; Nagakura, T.; Nakamura, N.; Shichijo, K.;

Saito, N 341

Nonsteroidal Antiinflammatory Drugs Induce UV-Dependent

Histamine and Leukotriene Release from Peripheral $\mathrm{Hu}$

man Leukocytes

Ring, J.; Przybilla, B.; Ruzicka, T 344

Airway Hyper-Reactivity and Eosinophilia in Rats Treated

with Sephadex Particles

Laycock, S.M.; Smith, H.; Spicer, B.A 347 
Eosinophil Chemotactic Activity in Allergic Patients during the Birch Pollen Season: The Effect of Immunotherapy

Rak, S.; Håkansson, L.; Venge, P 349

Goblet Cells

Structure and Function of Intestinal Mucin: Developmental

Aspects

Snyder, J.D.; Walker, W.A 351

Immune Regulation of Goblet Cell Development

Ahlstedt, S.; Enander, $1 \quad 357$

Regulation of the Delayed Hypersensitivity Reaction in the Lung

Reflected as Mononuclear, Mast Cell and Mucus Cell Appear

ance after T Helper Cell Depletion and Adoptive Transfer

Enander, I.; Ulfgren, A.-K; Nygren, H.; Holmdahl, R.;

Klareskog, L.; Larsson, P.; Ahlstedt, S 361

Interleukin-1 Induces Mucus Secretion from Mouse Intestinal Explants Han, V.; Resau, J.;

Prendergast, R.; Scott, A.; Levy, D.A. . 364

Neurotransmitters and Immune Reactivity

Substance P and Calcitonin Gene-Related Peptide: Effects on

Mast Cells and in Human Skin

Foreman, J.C 366

Inflammatory Mediators, Tachykinins and Enkephalinase in

Airways

Lazarus, S.C.; Borson, D.B.; Gold, W.M.; Nadel, J.A. ... 372 Effect of Capsaicin on Bronchial

Reactivity and Inflammation

in Sensitized Adult Rats

Alving, K; Ulfgren, A.-K; Lundberg, J.M.; Ahlstedt, S. . 377 Chemiluminescence Response of

Polymorphonuclear Leukocytes in Atopic Dermatitis

Schöpf, E.; Kapp, A 380

Regulation of IgE Mediated Disorders

T Cell Factors Involved in the Regulation of the IgE Synthesis

Ishizaka, K; Jardieu, P.; Akasaki, M.; Iwata, M 383

Regulation of the Human Allergic Response

Geha, R.S.; Leung, D.Y.M 389

Recombinant Human IgE

Gould, H.J.; Helm, B.A.; Marsh, P.J.; Geha, R.S 392

Functional Heterogeneity within the Human Peripheral Blood

B Cell Pool Engaged in IgE Synthesis

Turner, K.J.; Holt, B.J.; Cameron, K.J.; Holt, P.G 394

Seasonal Variations in in vitro Synthesis of Rye Pollen-Specific

IgE by Human Peripheral Mononuclear Cells. Functional

Heterogeneity within the IgE-B Pool

Turner, K.J.; Siemensma, N.P.; Krska, K; Cameron, K.J. . 398 Synthesis and Regulation of the IgE Receptor on B Lymphocyte

Cell Lines

Conrad, D.H.; Keegan, A.; Rao, M.; Lee, W.T 402

Human T Hybridoma-Derived Immunoglobulin-Binding Factors 
Stadler, B.M.; Gauchat, D.; Hildbrand, M.-L.; Yang, X.;

Week, A.L. de 405

Generation of Cell-Derived Factors in vitro Which Modulate

IgE Synthesis

Pfeiffer, P.; Rauschen, I.; Bujanowski, J.; König, W 408

VI

Contents

In vitro IgE Synthesis Induced by Human T Cell Clones in Normal B Cells and Its Suppression by Heterogenous T Cell Populations Romagnani, S.; Del Prete, G.F.; Maggi, E.; Ricci, M. ... 411 A Mechanism for the Suppression of Ongoing IgE Synthesis

Sherr, E.H.; Saxon, A 414

Effects of Cyclophosphamide Treatment and Gamma Irradia

tion of SJL Mice on the IgE Antibody Response and the

Nature of IgE-Binding Factors

Akasaki, M.; Ishizaka, K 417

Natural Killer Cell Interaction with IgE in the Control of Ongo

ing Human IgE Synthesis

Kimata, H.; Saxon, A 419

Essential Fatty Acids in Serum Lecithin of Children with Atopic

Dermatitis and in Umbilical Cord Serum of Infants with

High or Low IgE Levels

Strannegård, I.-L.; Svennerholm, L.; Strannegård, Ö422

Occupational Allergies

Current Concepts in the Pathogenesis of Occupationally In

duced Allergic Pneumonitis

Salvaggio, J.E 424

Acid Anhydrides and Asthma

Newman Taylor, A.J.; Venables, K.M.; Durham, S.R.;

Graneek, B.J.; Topping, M.D 435

Sawmill Alveolitis in Sweden

Belin, L $\quad 440$

Physicochemical Characterization of a Major Protein Allergen, Derp I, from the House Dust

Mite, Dermatophagoides ptero-nyssinus. Amino Acid Analysis and Circular Dichroism Studies

Stewart, G.A.; Simpson, R.J.; Thomas, W.R.; Turner, K.J. 444

Level of Indoor Allergens in Dust from Homes of Allergic and

Non-Allergic Individuals

Schwartz, B.; Lind, P.; Løwenstein, H

Allergy to Laboratory Animals: Characterization and Source of

Two Major Mouse Allergens, Ag 1 and Ag 3

Longbottom, J.L.; Price, J.A 450

Percutaneous Sensitisation to House Dust Mite May Occur Nat

urally in Eczema

Carswell, F.; Thompson, S.J 453 
The Relationship between Total Serum IgE and Castor Bean-Specific IgE Antibodies in Castor Bean-Sensitive Patients from Marseilles Thorpe, S.C.; Kemeny, D.M.; Panzani, R.; Lessof, M.H. .456

Side Chain-Specific Lymphocyte Responses in Workers with

Occupational Allergy Induced by Penicillins

Stejskal, V.D.M.; Forsbeck, M.; Olin, R 461

Antigenic Challenge via the Airway Alters the Permeability of

the Trachea in Sensitized Rats

Carswell, F.; Mukherjee, S.; Heap, P 465

A Canine Model for the Study of Hapten-Specific Suppression of

IgE-Mediated Bronchoconstriction and Anaphylaxis

Kepron, W.; Jackson, C.-J.; Sehon, A.H 468

Primary and Secondary Immunodeficiency

HTLV-III/LAV and the Origin and Pathogenesis of AIDS

Gallo, R.C.; Robert-Guroff, M.; Wong-Staal, F.; Reitz, M.S.,

Jr.; Arya, S.K.; Streicher, H.Z471

Immunoglobulin G Subclass Deficiencies

Söderström, T.; Söderström, R.; Avanzini, A.; Brandtzaeg,

P.; Karlsson, G.; Hanson, L. $\AA \quad 476$

Immunohistochemical Study of Nasal Mucosa in Patients with

Common Variable Immunodeficiency

Karlsson, G.; Brandtzaeg, P.; Hansson, G.; Petruson, B.;

Björkander, J.; Hanson, L.Å 481

Immunohistochemical Study of Nasal Mucosa in Patients with

Selective IgA Deficiency (with 1 color plate)

Brandtzaeg, P.; Karlsson, G.; Hansson, G.; Petruson, B.;

Björkander, J.; Hanson, L.A 483

Comparison of the Frequency of Atopic Diseases in Children

with Severe and Partial IgA Deficiency

Plebani, A.; Monafo, V; Ugazio, A.G.; Monti, C; Avanzini,

M.A.; Massimi, P.; Burgio, G.R 485

Screening for Anti-HTLV-HI/LAV Antibody in High-Risk Sub

jects: Sensitivity and Specificity of Commercial Tests

Lantin, J.P.; Peitrequin, R.; Frei, P.C 487

Effect of Growth Factors on the Proliferation of Thymocytes in

Different Functional and Anatomical Compartments

Sandberg, G.; Ernström, U.; Söder, O.; Kölare, S 490

New Advances in Immunopharmacology of Allergic Diseases

Pharmacology of Upper Airways Challenge

Proud, D.; Kagey-Sobotka, A.; Naclerio, R.M.; Lichtenstein,

L.M 493

Primary and Secondary Effector Cells in the Pathogenesis of Bronchial Asthma

Holgate, S.T.; Twentyman, O.P.; Rafferty, P.; Beasley, R.;

Hutson, P.A.; Robinson, C; Church, M.K 498

Some Studies on Human Pulmonary Mast Cells Obtained by Bronchoalveolar Lavage and by Enzymic Dissociation of Whole Lung Tissue 
Pearce, F.L.; Flint, K.C.; Leung, K.B.P.; Hudspith, B.N.;

Seager, K.; Hammond, M.D.; Brostoff, J.; Geraint-James,

D.; Johnson, N.Mel 507

The Development of a New Agent for the Treatment of Inflam

matory/Allergic Conditions

Cairns, H.; Orr, T.S.C 513

Mechanisms in Asthma Using the Technique of Bronchoalveo

lar Lavage

Wardlaw, A.J.; Collins, J.V.; Kay, A.B 518

The Role of Leukotriene-Inducing and -Metabolizing Enzymes in Inflammation

König, W.; Bremm, K.D.; Brom, H.J.; Köller, M.; Knöller,

J.; Raulf, M.; Schönfeld, W.; Stüning, M 526

Betamethasone Modulates the Biological Function of Human

Polymorphonuclear Leukocytes

Marone, G.; Siri, L.; Genovese, A.; Condorelli, M 532

Antiasthmatic Effects of Onions. Inhibition of Platelet-Activating Factor-Induced Bronchial

Obstruction by Onion Oils

Dorsch, W.; Ettl, M.; Hein, G.; Scheftner, P.; Weber, J.;

Bayer, T.; Wagner, H 535

Application of Histamine-Induced Conjunctivitis to the Assess

ment of a Topical Antihistamine, Levocabastine

Feinberg, G.; Stokes, T.C 537

Contents

VII

Effect of Thromboxane A2 Synthetase Inhibitor on Immediate-Type Hypersensitivity Reactions Nakagawa, T.; Miyamoto, T.; Urata, C; Mano, K.; Yukawa, T.; Makino, S 539

Effect of a New Selective H 1 Receptor Antagonist (Levocabastine) in a Nasal and Conjunctival Provocation Test

Pécoud, A.; Zuber, P.; Kolly, M 541

Antagonism of Picumast and Ketotifen against Histamine, Ace-

tylcholine, LTC4, Slow-Reacting Substance of Anaphylaxis

and Barium Chloride in the Guinea Pig Ileum Bioassay

Wilhelms, O.-H $\quad 544$

Inhibition Profiles of Picumast and Ketotifen on the in vitro

Release of Prostanoids, Slow-Reacting Substance of Ana

phylaxis, Histamine and Enzyme from Human Leukocytes

and Rat Alveolar Macrophages

Wilhelms, O.-H 547

Double-Blind, Placebo-Controlled Immunotherapy with a High-Molecular-Weight, Formalinized

Allergoid in Grass Pollen Allergy

Bousquet, J.; Frank, E.; Soussana, M.; Hejjaoui, A.; Maasch,

H.J.; Michel, F.-B 550

Asthma and Serum IgE Levels in Children in a Desert Country

Strannegård, I.-L.; Strannegård, Ö 553 
Author Index 555 